\title{
PRESENCE OF ALLEGED PREDATORY JOURNALS IN BIBLIOGRAPHIC DATABASES: ANALYSIS OF BEALL'S LIST
}

\section{Presencia de revistas supuestamente depredadoras en bases de datos bibliográficas: análisis de la lista de Beall}

Marta Somoza-Fernández, Josep-Manuel Rodríguez-Gairín and Cristóbal Urbano

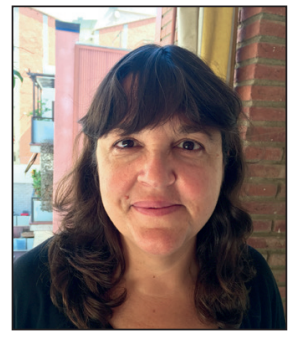

Marta Somoza-Fernández has degrees in both Contemporary History (1989) and Cultural Anthropology (1995), plus a PhD in Documentation (2009) from the University of Barcelona (UB). As well as a manager for the UB Library Health Sciences Online Searching Service until 2002, she has also been a lecturer at the UB Faculty of Library and Information Science since 1999. Her research focuses on document databases, information retrieval, bibliometric studies and user training. She is now coordinator for the research team that developed MIAR (Information Matrix for the Analysis of Journals).

http://orcid.org/0000-0002-4769-9010

msomoza@ub.edu

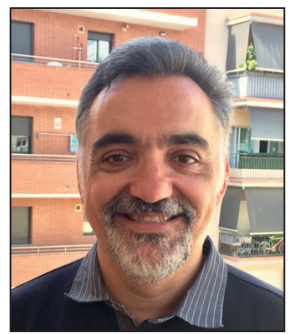

Josep-Manuel Rodríguez-Gairín has a PhD in Documentation (2002) from the University of Barcelona $(U B)$, where he is currently a lecturer, coordinates computing classes and advises on technological matters. He has implemented the infrastructure of projects such as Temaria (Electronic journals on Library and Information Science); the BiD journal (University texts on Library and Information Science); MIAR (Information Matrix for Journal Analysis); Alehoop (Online resources for research development); EXIT (Directory of Information Handling Experts); IraLIS (International registry of authors - Links to identify scientists), etc. He is a member of Ciepi, ThinkEPI and the executive board of the E-LIS repository. Josep-Manuel is also founder of the company Kronosdoc, dedicated to the assessment and development of document management systems.

http://orcid.org/0000-0001-8375-7911

rodriguez.gairin@ub.edu

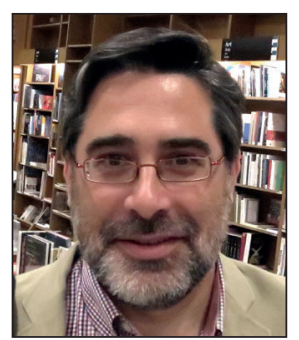

Cristóbal Urbano is a professor of the Faculty of Library and Information Science at the University of Barcelona $(U B)$, where his main fields are Reference resources and Information services. He is member of the research group i-Viu: Information, Value and Use (2009 SGR 846, Generalitat de Catalunya), dedicated to the evaluation of research in Human and Social Sciences, and to the study of digital bibliographic resources, among others. Cristóbal also teaches web analytics and usage metrics of e-resources as part of the Master's Degree in Digital Content Management (Universitat de Barcelona / University Pompeu Fabra). He is also part of the research team that developed MIAR (Information Matrix for the Analysis of Journals).

http://orcid.org/0000-0003-0935-6436

urbano@ub.edu 


\begin{abstract}
The presence of journals considered predatory are analysed in various bibliographic databases and in the Directory of Open Access Journals (DOAJ). Of the list produced by Jeffrey Beall of possible or probable predatory open access academic journals, 944 of those are reviewed, cross-referencing their ISSN with the Information Matrix for the Analysis of Journals (MIAR) developed at the University of Barcelona. It is then determined whether these journals appear in citation indexes such as Web of Science or Scopus, in multidisciplinary databases, in specialised databases or in the DOAJ directory. The study concludes that there is no significant widespread presence of predatory journals in bibliographic databases, although some such as Emerging Sources Citation Index, Veterinary Science Database or DOAJ show somewhat higher values than expected, and so should be monitored and revised in the future by database producers or by Beall's list.
\end{abstract}

\title{
Keywords
}

Predatory journals; Beall's list; MIAR; Bibliographic databases; Open access; Journal evaluation.

\section{Resumen}

Se analiza la presencia de revistas consideradas depredadoras en varias bases de datos bibliográficas y en el directorio DOAJ. Se revisan 944 revistas de la lista de posibles o probables revistas académicas depredadoras de acceso abierto elaborada por Jeffrey Beall, cruzando sus ISSN con la Matriz de información para el análisis de revistas (MIAR) elaborada en la Universitat de Barcelona. Se determina si las revistas aparecen en los índices de citas del Web of Science, en Scopus, en bases de datos multidisciplinares, en bases de datos especializadas o en DOAJ. El estudio concluye que no existe una presencia significativa generalizada de revistas depredadoras en las bases de datos de indización y resumen, aunque bases como Emerging Sources Citation Index, Veterinary Science Database o DOAJ muestran cifras algo más elevadas que deberán ser seguidas y revisadas en un futuro por los productores de bases de datos o por la lista de Beall.

\section{Palabras clave}

Revistas depredadoras; Lista de Beall; MIAR; Bases de datos bibliográficas; Acceso abierto; Evaluación de revistas.

Somoza-Fernández, Marta; Rodríguez-Gairín, Josep-Manuel; Urbano, Cristóbal (2016). “Presence of alleged predatory journals in bibliographic databases: Analysis of Beall's list”. El profesional de la información, v. 25, n. 5, pp. 730-737.

https://doi.org/10.3145/epi.2016.sep.03

\section{Introduction}

In the world of scientific journals, the term predatory journals was introduced by Jeffrey Beall, a librarian in the University of Colorado Auraria Library. He noted a somewhat unethical use of the "golden road" of open access by some journals and publishers that were trying to make money out of authors pressured by "publish or perish" and who were willing to pay Article Processing Charges (APC). Some journals requested large sums from authors to quickly publish their articles in open access without many barriers. Alongside benchmarks such as plagiarism, insufficient or false contact information, non-adherence to editor associations' codes of conduct, laxity in the peer review system and the large number of texts published in one year, this put into doubt the scientific accuracy of open access. It seemed that open access was being corrupted (Beall, 2012c; Beall, 2013). Beall published a list with over 50 such benchmarks in August 2012 (Beall, 2012a):

https://scholarlyoa.com/2012/08/04/criteria-for-determiningpredatory-open-access-publishers

When these observations were circulated on the Internet, scientists pointed out other practices of the same style. That led him to publish a second list with more detailed benchmarks (Beall, 2012b) that looked at business models, editorial practices such as sending out bulk emails to authors asking for articles, high costs for fast publishing (Truth, 2012) or the transparency and integrity of the journal, among others.
At the same time, the large amount of evidence and information that Beall received led him to develop and maintain a list of "Potential, possible, or probable predatory scholarly open-access publishers" employing such bad practices: https://scholarlyoa.com/publishers

He also published a list of journals with the same characteristics not associated to any editor: https://scholarlyoa. com/individual-journals

Clearly, these actions do not lack controversy. Prestigious members of the scientific community demand strong action against the increase of these predatory practices (Clark; Smith, 2015). By contrast, Beall's list has been subject to a range of criticism, for its perception as a completely personal and, to some extent, personalist initiative, as well as for its cultural, linguistic and prevention biases towards open access in general (Anderson, 2015; Berger; Cirasella, 2015; Crawford, 2014a; Velterop, 2015).

The very definition of "predatory journal" linked only to open access, opens a debate about whether many other commercial journals that are not in open access should also merit such a qualification. As such, there is a certain stigma to open access by the way this list was presented and the selection of titles included.

In any case, the phenomenon of predatory journals is a symptom of change in the business model of open access related scientific publishing. The main "client" becomes the author, concerned about raising the profile of their curricu- 


\section{MIAR}

Matriz de Información para el Análisis de Revistas Versión 2016 live

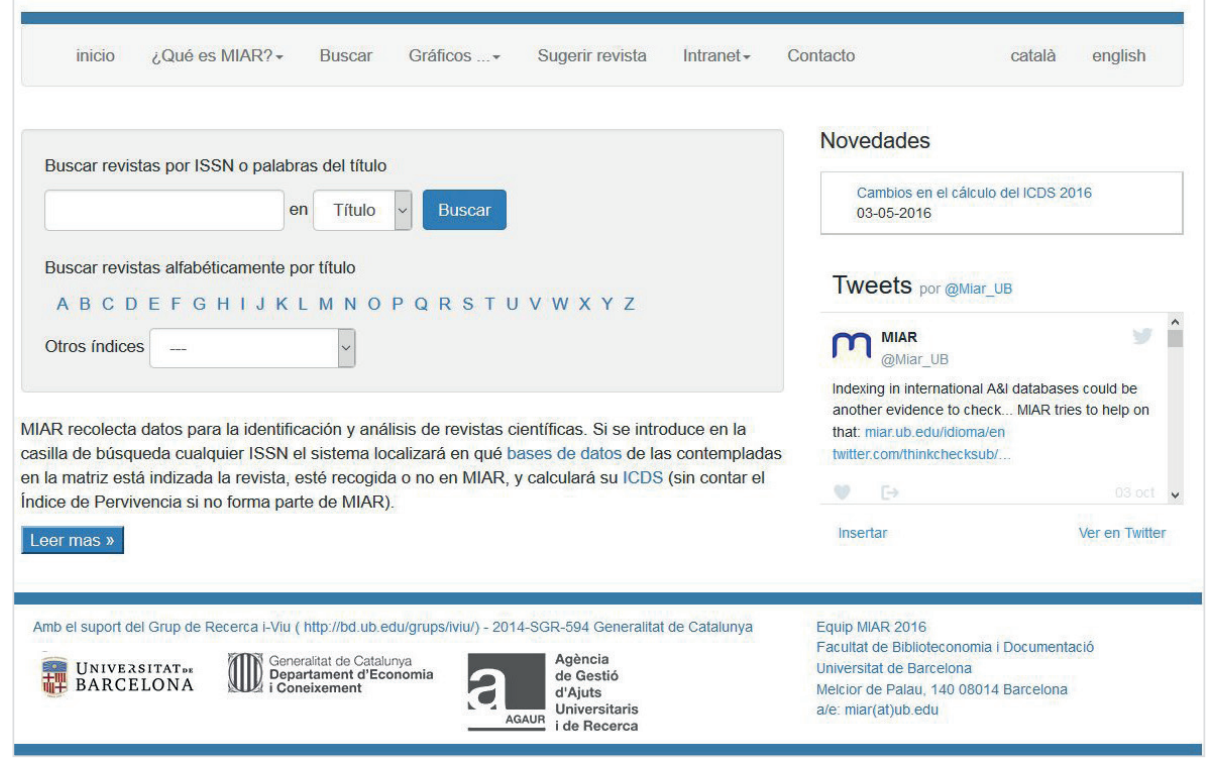

http://miar.ub.edu exploring every title to evaluate the relevance of the journals included. We understand that compliance with ethical criteria and minimum editorial quality should be conditions for any database in its task of selecting titles to index. Therefore, a very high presence of titles from Beall's list in a given database should be the focus of attention, to determine whether the error is by the database producer in the title selection, or is an incorrect judgment by Beall in determining a given publication as predatory. In this paper, we attempt to provide the basic information to permit further studies to assess each given case collected by Beall, a practice of detailed analysis that so far has been object of very few studies (Crawford, 2014b; Shen; Björk, 2015). lum, to the detriment of readers and libraries. This area of business naturally generates economic and ethical conflicts, and is beginning to reach the courts (Straumsheim, 2016). As a result, in the future the judicial outcome and the codes of conduct of publishers' associations will undoubtedly help to more precisely define and reach consensus over the definition and identification of such journals. Evidence of that legal path to future regulation, is a malpractice case from the US Federal Trade Commission (FTC) in its recent lawsuit against a predatory publisher:

"the FTC says, many articles aren't peer-reviewed, many of the scientists listed on editorial boards never agreed to appear there, and the publisher effectively holds manuscripts ransom by hiding its fees until the papers have been accepted, making it difficult for researchers to pull their articles and submit to other journals. The complaint also accuses the companies of deceiving scientists and the public through their promotion of conferences - meetings, the company boasts untruthfully, attended by high-profile researchers" (Oransky; Marcus, 2016).

In any case, Beall's 50 criteria and journal and publisher's listings are some of the main study sources for the phenomenon of predatory journals, along with the journals that for some reason, have been rejected from the Directory of Open Access Journals (DOAJ) in the recent review process that this directory recently conducted (DOAJ, 2016). However, Beall's list has a major impact and influence as a source exclusively dedicated to this type of journals. For this reason, it is renowned as a useful reference to study their visibility in international databases. It can also be used to indirectly assess the information gathered by Beall's list: journals that also appear indexed in databases can point to errors of assessment by Beall, or to symptoms of carelessness of database producers when deciding what titles to index.

This paper is a preliminary analysis of the situation, without
While other authors (Nelson; Huffman, 2015) have already analysed the presence of predatory journals in some specific databases, this research takes advantage of the wide coverage of the MIAR matrix (Rodríguez-Gairín; SomozaFernández; Urbano, 2011) to verify to what extent the journals considered predatory have been selected for appearing in more than 100 bibliographic databases. A journal that has a wide presence in databases does not exclude it from being predatory, but can focus the reader's attention on the cause of inclusion. In the same way, a database accepting more than average predatory journals might lead to a review of the inclusion criteria.

\section{Beall's list along with journals rejected by DOAJ are the main sources of stu- dying the phenomenon of predatory journals}

\section{Methodology}

The aim of this study is the list of "potential, possible, or probable predatory scholarly open-access journals" developed by Jeffrey Beall. The aim of this study is not the analysis of publishers that have predatory practices, but of the list of journals obtained from:

\section{https://scholarlyoa.com/individual-journals}

We have considered all titles on the list regardless of their first publication date. Although from the instant a journal appears until it is indexed in a database, logically some time passes and this limits the possibilities of the latest titles to be included.

In order to detect these journals in databases, it was necessary to know their ISSN, data not included in Beall's list. In the first phase, links were extracted and checked with the program Integrity Plus. Once the links were obtained, a spider 
was used to automatically check the journal's home page to acquire the ISSN. In principle the sequences approved using the ISSN validation algorithm were accepted, and the invalid ones were manually checked, as in many cases the ISSN appears as an image or did not follow the standard structure of four digits, a hyphen and four or three digits plus the letter $\mathrm{X}$.

We are aware that the automatic processing can be misleading in cases where the page includes a different valid ISSN, such as lists of titles from the same publisher or references to other journals. An interesting case is Journal of Natural Products (ISSN: 0974-5211), where in the page's footer the editors include a revealing comment in poor English:

"Note: One thing must be noted that this journal (Journal of Natural Products) - ISSN 0974-5211; is a new, free assess, only on-line publishing, Annual science journal published from India and this is not related or resembled in any way with already publishing monthly journal 'Journal of Natural Products' ISSN 0163-3864 by 'American Chemical Socity"' (sic).

Citation obtained on $12^{\text {th }}$ of September 2016 from http://journalofnaturalproducts.com

In this case, the spider assigned the Indian journal both ISSNs, so it was identified as being present in all the databases where the American journal was indexed. That is why those publications present in many databases were manually reviewed.

In cases where the ISSN did not appear on the first page, a secondary page would be searched or in a pdf on the journal's website. The option of locating an ISSN by Google searching the journal title sites other than the Beall-supplied URLs was discarded. This is due to the chance it could be mistaken for other journals with the same title, either by coincidence or by impersonation, a malpractice known as hijacked journals, which has boomed over the last year (Jalalian; Mahboobi, 2014; Matthews, 2016; Vargas, 2016).

Once the ISSN of the journals are obtained, these would be checked in MIAR to see if they were indexed in:

- Web of Science

Science Citation Index Expanded (SCIE)

Social Science Citation Index (SSCI)

Arts and Humanities Citation Index ( $\mathrm{AHCl})$

Emerging Sources Citation Index (ESCI)

- Scopus

- Multidisciplinary databases

- Specialised databases

- DOAJ

Table 1. Verifying the journal URLs

\begin{tabular}{|l|c|}
\hline \multicolumn{1}{|c|}{ HTTP response } & Total \\
\hline $200-30 X(o k)$ & 1,087 \\
\hline $40 X$ & 26 \\
\hline $50 X$ & 5 \\
\hline Error & 2 \\
\hline Server not found & 36 \\
\hline The request timed out & 20 \\
\hline
\end{tabular}

A list of the 108 databases analysed is available from MIAR. An automated system periodically revises the public URLs of producers in order to keep the data up to date. http://miar.ub.edu/databases/GRUPO/G

\section{Results}

Of 1,172 journals analysed, the link checker correctly located 1,087 . Table 1 lists the responses obtained.

After performing the automatic extraction of the ISSNs and subsequent manual checking, ISSNs were detected in 944 titles (86.84\%) which were analysed in MIAR to locate their presence in databases.

Table 2 lists the journals included in any of the Web of Science $(\mathrm{SCl}, \mathrm{SSCl}$ and $A \& \mathrm{HCl})$ citations databases, in the Emerging Sources Citation Index (ESCl) and Scopus. From Beall's list, 863 journals were not indexed in any of these.

The 9 journals present in Science Citation Index Expanded shown in table 3 are sorted by decreasing order of ICDS value (calculated in MIAR), to analyse the presence (and therefore visibility) of the journals in databases.

http://miar.ub.edu/about-icds

The ICDS (Secondary Composite Index Diffusion) is an indicator that shows the visibility of the journal in various scientific databases of international scope, or in repertoires evaluating journals. A high ICDS means that the journal is present on many sources of information of international relevance.

On the other hand, it is important to highlight some cases of hijacked journals. For example, Journal of psychology and theology was initially found in the Arts and Humanities Citation Index and Social Science Citation Index. http://www.dinz.info

Although the main page did not include any ISSNs, the archive section was manually checked and the ISSNs identified in the PDF version of the articles. However, the overall look of the publication and the URL triggered suspicions, so it was decided to investigate further. Although a title search on Google positioned this one first, on the first page of results it was possible to identify the same publication with another url (journals.biola.edu/jpt). This is a clear case of a hijacked journal. Reviewing some of the PDFs it was found that the texts corresponded to originals that had previously

Table 2. Presence in Web of Science and Scopus

\begin{tabular}{|l|c|c|c|}
\hline \multicolumn{1}{|c|}{ Databases } & $\begin{array}{c}\text { Total N. of jour- } \\
\text { nals indexed in } \\
\text { databases }\end{array}$ & $\begin{array}{c}\text { Journals } \\
\text { indexed in } \\
\text { Beall's list }\end{array}$ & $\%$ \\
\hline $\begin{array}{l}\text { Science Citation Index } \\
\text { Expanded }\end{array}$ & 8,859 & 9 & 0.10 \\
\hline $\begin{array}{l}\text { Social Sciences } \\
\text { Citation Index }\end{array}$ & 3,242 & 1 & 0.03 \\
\hline $\begin{array}{l}\text { Arts and Humanities } \\
\text { Citation Index }\end{array}$ & 1,778 & 1 & 0.06 \\
\hline $\begin{array}{l}\text { Emerging Sources } \\
\text { Citation Index }\end{array}$ & 4,616 & 28 & 0.61 \\
\hline Scopus & 22,409 & 56 & 0.25 \\
\hline
\end{tabular}


Table 3. Journals from Beall's list indexed in Science Citation Index Expanded

\begin{tabular}{|l|c|}
\hline \multicolumn{1}{|c|}{ Journal } & ICDS \\
\hline $\begin{array}{l}\text { Journal of environmental biology } \\
\text { http://www.jeb.co.in }\end{array}$ & 11.0 \\
\hline $\begin{array}{l}\text { Cellular and molecular biology } \\
\text { http://www.cellmolbiol.com }\end{array}$ & 11.0 \\
\hline $\begin{array}{l}\text { Romanian biotechnological letters } \\
\text { http://www.rombio.eu }\end{array}$ & 10.8 \\
\hline $\begin{array}{l}\text { African journal of traditional, complementary and alternative } \\
\text { medicines } \\
\text { http://journals.sfu.ca/africanem/index.php/ajtcam/index }\end{array}$ & 10.6 \\
\hline $\begin{array}{l}\text { International journal of electrochemical science } \\
\text { http://www.electrochemsci.org }\end{array}$ & 10.5 \\
\hline $\begin{array}{l}\text { Journal of nonlinear science and applications } \\
\text { http://www.emis.de/journals/TJNSA }\end{array}$ & 10.4 \\
\hline $\begin{array}{l}\text { Oncotarget } \\
\text { http://www.impactjournals.com/oncotarget/index.php?journal } \\
\text { =oncotarget\&page=index }\end{array}$ & 10.3 \\
\hline $\begin{array}{l}\text { Tehnički vjesnik } \\
\text { http://www.tehnicki-vjesnik.com/web/public/page }\end{array}$ & 9.5 \\
\hline $\begin{array}{l}\text { Aging } \\
\text { http://www.impactaging.com/index.html }\end{array}$ & 9.4 \\
\hline
\end{tabular}

ICDS = Secondary Composite Index Diffusion, calculated up to 11 points in MIAR

published in other legitimate journals. Possibly the authors of these texts did not know about these fraudulent practices. For example:

Sánchez-Navarro, J. P., Martínez-Selva, J. M., Torrente, G., \& Román, F. (2015). Psychophysiological, behavioral, and cognitive indices of the emotional response: A factor-analytic study.

http://www.dinz.info/attachments/article/17/1-7-2015-25-35.pdf

in reality corresponds to:

Sánchez-Navarro, J. P., Martínez-Selva, J. M., Torrente, G., \& Román, F. (2008). Psychophysiological, behavioral, and cognitive indices of the emotional response: A factor-analytic study. The Spanish journal of psychology, 11(01), 16-25.

To rule out such practices, in the case of the 9 journals included in the Science Citation Index Expanded, the legitimacy of the URLs has been verified, discarding their presence on the list

\section{https://scholarlyoa.com/other-pages/hijacked-journals}

and checking that the contents of the original articles corresponded to the ones indexed in the Web of Science. This fact does not necessarily stop these from being included in Beall's list. This is the case for example of Oncotarget, included by Beall for being too careless in the peer review, without denying that this is a high-impact journal and dissemination.

https://scholarlyoa.com/2016/04/19/oncotargets-peerreview-is-highly-questionable

The 28 journals present in the Emerging Sources Citation Index are shown in table 4 in decreasing order of ICDS value, which measures their dissemination via databases, according to MIAR.

Of the 944 journals analysed, 56 appear in Scopus, most of them coinciding with those present in Science Citation Index Expanded. This figure, although high, should be con-
Table 4. Journals present in Beall's list included in the Emerging Sources Citation Index

\begin{tabular}{|c|c|}
\hline Journal & ICDS \\
\hline $\begin{array}{l}\text { Journal of computers } \\
\text { http://wWw.jcomputers.us }\end{array}$ & 9.5 \\
\hline $\begin{array}{l}\text { International journal of pharmaceutical sciences and research } \\
\text { http://WwW.ijpsr.com/index.html }\end{array}$ & 9.3 \\
\hline $\begin{array}{l}\text { Modern journal of language teaching methods } \\
\text { http://www.mjltm.com/index.php }\end{array}$ & 8.5 \\
\hline $\begin{array}{l}\text { Journal of experimental biology and agricultural sciences } \\
\text { http://www.jebas.org }\end{array}$ & 8.5 \\
\hline $\begin{array}{l}\text { International journal of medical research \& health sciences } \\
\text { http://ijmrhs.com }\end{array}$ & 8.5 \\
\hline $\begin{array}{l}\text { European journal of sustainable development } \\
\text { http://www.ecsdev.org }\end{array}$ & 8.5 \\
\hline $\begin{array}{l}\text { Biointerface research in applied chemistry } \\
\text { http://biointerfaceresearch.com }\end{array}$ & 8.5 \\
\hline $\begin{array}{l}\text { Journal of IMAB } \\
\text { http://WWW.journal-imab-bg.org }\end{array}$ & 7.8 \\
\hline $\begin{array}{l}\text { International journal of computer science and information } \\
\text { security } \\
\text { https://sites.google.com/site/ijcsis }\end{array}$ & 7.3 \\
\hline $\begin{array}{l}\text { International journal of collaborative research on internal } \\
\text { medicine \& public health } \\
\text { http://www.iomcworld.com/ijcrimph }\end{array}$ & 7.3 \\
\hline $\begin{array}{l}\text { Hiperboreea journal } \\
\text { http://revistahiperboreea.ro }\end{array}$ & 7.1 \\
\hline $\begin{array}{l}\text { International journal of pediatrics } \\
\text { http://ijp.mums.ac.ir }\end{array}$ & 7.0 \\
\hline $\begin{array}{l}\text { Journal of mathematics and computer science } \\
\text { http://www.tjmcs.com/index.php }\end{array}$ & 6.5 \\
\hline $\begin{array}{l}\text { Journal of intercultural ethnopharmacology } \\
\text { http://www.jicep.com }\end{array}$ & 6.5 \\
\hline $\begin{array}{l}\text { Journal of clinical and analytical medicine } \\
\text { http://www.jcam.com.tr/en/index.php }\end{array}$ & 6.5 \\
\hline $\begin{array}{l}\text { International journal of renewable energy research } \\
\text { http://www.ijrer.org/ijrer/index.php/ijrer/index }\end{array}$ & 6.5 \\
\hline $\begin{array}{l}\text { International journal of life science and pharma research } \\
\text { http://www.ijlpr.com }\end{array}$ & 6.5 \\
\hline $\begin{array}{l}\text { International journal of advanced and applied sciences } \\
\text { http://wWw.science-gate.com/IJAAS.html }\end{array}$ & 6.5 \\
\hline $\begin{array}{l}\text { Asian journal of pharmaceutical research and health care } \\
\text { http://jprhc.in/index.php }\end{array}$ & 6.5 \\
\hline $\begin{array}{l}\text { Annals of Eurasian medicine } \\
\text { http://www.aemed.eu/en/index.php }\end{array}$ & 6.5 \\
\hline $\begin{array}{l}\text { International journal of computer science and network security } \\
\text { http://ijcsns.org }\end{array}$ & 4.5 \\
\hline $\begin{array}{l}\text { International journal of physiotherapy } \\
\text { https://www.ijphy.org }\end{array}$ & 3.8 \\
\hline $\begin{array}{l}\text { International journal of humanities and cultural studies } \\
\text { http://ijhcschiefeditor.wix.com/ijhcs }\end{array}$ & 3.8 \\
\hline $\begin{array}{l}\text { International letters of natural sciences } \\
\text { http://www.ilns.pl }\end{array}$ & 3.5 \\
\hline $\begin{array}{l}\text { International journal of pure and applied zoology } \\
\text { http://wWw.ijpaz.com/index.php/ijpaz }\end{array}$ & 3.5 \\
\hline $\begin{array}{l}\text { International journal of pharmaceutical and phytopharmaco- } \\
\text { logical research } \\
\text { http://www.eijppr.com }\end{array}$ & 3.5 \\
\hline $\begin{array}{l}\text { Entomology and applied science letters } \\
\text { http://easletters.com }\end{array}$ & 3.5 \\
\hline $\begin{array}{l}\text { Bioscience biotechnology research communications } \\
\text { http://www.bbrc.in }\end{array}$ & 3.5 \\
\hline
\end{tabular}


Table 5. Journals present in Academic Search Premier

\begin{tabular}{|l|c|}
\hline \multicolumn{1}{|c|}{ Journal } & ICDS \\
\hline $\begin{array}{l}\text { Journal of nonlinear science and applications } \\
\text { http://www.emis.de/journals/TJNSA }\end{array}$ & 10.4 \\
\hline $\begin{array}{l}\text { Journal of psychology and theology } \\
\text { http://www.dinz.info }\end{array}$ & 10.0 \\
\hline $\begin{array}{l}\text { Asian journal of chemistry } \\
\text { http://www.asianjournalofchemistry.co.in/Home.aspx }\end{array}$ & 9.9 \\
\hline $\begin{array}{l}\text { Shiraz e-medical journal } \\
\text { http://emedicalj.com }\end{array}$ & 9.7 \\
\hline $\begin{array}{l}\text { Tehnički vjesnik } \\
\text { http://www.tehnicki-vjesnik.com/web/public/page }\end{array}$ & 9.5 \\
\hline $\begin{array}{l}\text { International journal of renewable energy research } \\
\text { http://www.ijrer.org/ijrer/index.php/ijrer/index }\end{array}$ & 6.5 \\
\hline $\begin{array}{l}\text { National journal of community medicine } \\
\text { http://www.njcmindia.org/home }\end{array}$ & 5.8 \\
\hline $\begin{array}{l}\text { Research opinions in animal and veterinary sciences } \\
\text { http://www.roavs.com }\end{array}$ & 5.0 \\
\hline $\begin{array}{l}\text { Indianjournal of medical research and pharmaceutical sciences } \\
\text { http://www.ijmrps.com }\end{array}$ & 5.0 \\
\hline $\begin{array}{l}\text { Science international (Lahore) } \\
\text { http://sci-int.com }\end{array}$ & 3.0 \\
\hline $\begin{array}{l}\text { Scholarly research exchange } \\
\text { http://srej.wc.lt }\end{array}$ & 3.8 \\
\hline $\begin{array}{l}\text { Pharmacie globale: International journal of comprehensive } \\
\text { http://pharmacie-globale.info }\end{array}$ & 3.0 \\
\hline $\begin{array}{l}\text { National journal of physiology, pharmacy, and pharmacology } \\
\text { http://www.njppp.com }\end{array}$ & 3.0 \\
\hline http://www.apjhs.com/index.html & Pacific journal of health sciences \\
\hline
\end{tabular}

sidered in the context of nearly 22,500 titles indexed by Scopus.

\section{Lately, another fraud to add to predatory} journals are the hijacked journals

Analysing other multidisciplinary databases, only 14 journals appear indexed. All 14 are in Academic Search Premier and one of them is in IBZ Online. Their titles are listed in table 5 .

Table 6. Presence of journals from Beall's list in one or more specialised databases

\begin{tabular}{|c|c|}
\hline Number of journals & Ocurrences in databases \\
\hline 812 & 0 \\
\hline 79 & 1 \\
\hline 25 & 2 \\
\hline 9 & 3 \\
\hline 4 & 4 \\
\hline 7 & 5 \\
\hline 2 & 6 \\
\hline 2 & 7 \\
\hline 2 & 8 \\
\hline 2 & 9 \\
\hline
\end{tabular}

Table 7. Number of journals from Beall's list located in each specialised database

\begin{tabular}{|l|c|}
\hline \multicolumn{1}{|c|}{ Specialised databases } & Journals \\
\hline Veterinary Science Database & 45 \\
\hline Inspec & 22 \\
\hline Communication Abstracts & 13 \\
\hline Aquatic Science \& Fisheries Abstracts (ASFA) & 12 \\
\hline MLA - Modern Language Association Database & 12 \\
\hline CAB Abstracts & 12 \\
\hline Aerospace Database & 11 \\
\hline Civil Engineering Abstracts & 11 \\
\hline Metadex & 10 \\
\hline Biotechnology Research Abstracts & 10 \\
\hline ERIC (Education Resources Information Center) & 10 \\
\hline Aqualine & 8 \\
\hline Ebsco Education Source & 8 \\
\hline Applied Science \& Technology Source & 7 \\
\hline Biosis & 7 \\
\hline Medline & 5 \\
\hline ABI/Inform & 4 \\
\hline EconLit & 4 \\
\hline Chemical Abstracts Core & 3 \\
\hline EMBase & 3 \\
\hline
\end{tabular}

Table 6 shows the number of journals from Beall's list in specialised databases. It has also been checked in which databases exists a greater number of journals (table 7). 812 journals are not indexed in any of these databases.

Another important fact to consider is presence in DOAJ. Of the 944 journals with ISSN, 143 (15.15\%) were located in the current list of DOAJ, after the cleansing of May 2016. This is a high figure, which should be weighed against the relevance of DOAJ's assessment or Beall's judgment in considering these to be predatory journals. In particular because DOAJ is conducting a thorough and ongoing monitoring process to cleanse their content (DOAJ, 2016). Table 8 shows the main causes and number of journals removed from DOAJ.

Table 8. Causes for removing journals from DOAJ

\begin{tabular}{|l|c|}
\hline \multicolumn{1}{|c|}{ Cause } & Journals \\
\hline Suspected editorial misconduct by publisher & 281 \\
\hline Inactive (has not published in the last calendar year) & 238 \\
\hline Journal not adhering to Best practice & 181 \\
\hline Website url no longer works & 128 \\
\hline Ceased publishing & 125 \\
\hline Journal is no longer open access & 56 \\
\hline Journal is not open access & 20 \\
\hline Has not published enough articles this calendar year & 10 \\
\hline Other & 19 \\
\hline
\end{tabular}

https://docs.google.com/spreadsheets/d/183mRBRqs2jOyPOqZWXN8dUd 02D4vLOMov_kgYF8HORM/edit?usp=sharing (checked on September 15 $5^{\text {th }} 2016$ ) 


\section{Conclusions}

The presence of predatory journals in Web of Science is scarce. Of 944 titles analysed, $9(0.95 \%)$ are in $S C I E$, and the title present in $\mathrm{AHCl}$ and $\mathrm{SSCl}$ corresponds to a hijacked journal. Perhaps this fact is due to the strict inclusion criteria of these databases, although it is necessary to monitor these as many of the predatory journals have emerged in the last two years, an insufficient period of time for those to be accepted in these databases.

The case of ESCI (which is also part of Web of Science) deserves special mention, as, although 28 titles from the total studied $(2.96 \%)$ may seem insignificant, the database has only recently

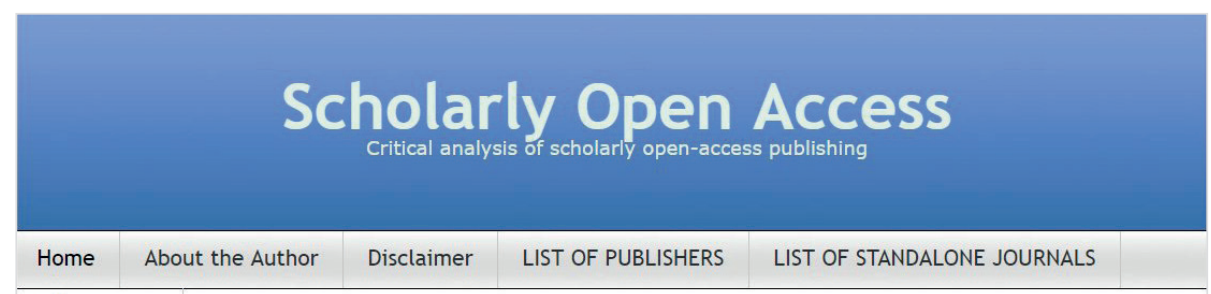

Other pages

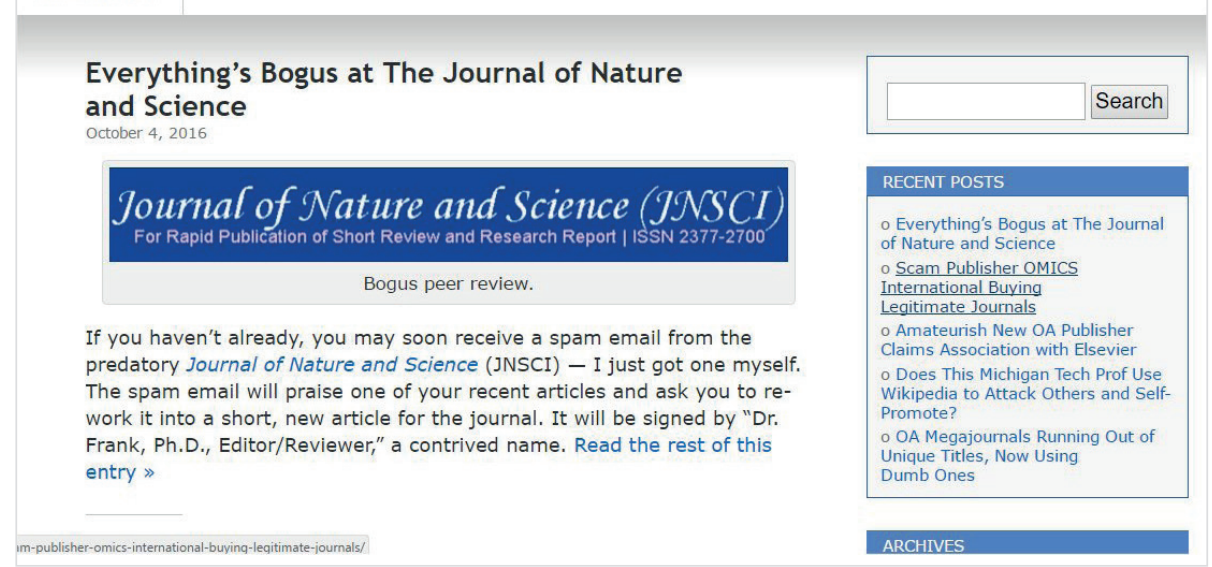

https://scholarlyoa.com appeared (Thomson Reuters, 2015) and as of September 2016 has 4,616 titles with an average of additions of 250 titles monthly in the last 5 months ${ }^{1}$.

Among the multidisciplinary databases analysed by MIAR, Academic Search Premier is the one that presents the highest number of predatory journals. However, 14 titles $(1.48 \%)$ in a database of more than 16,000 cannot be considered relevant.

Specialised databases such as Biosis, Medline, EMBase and Chemical Abstracts Core present few predatory journals: 7, 5, 3 and 3 respectively. Veterinary Science Database draws particular attention, which, considering it is smaller than the above $(5,726$ titles), contains 44 suspicious titles.

There is no significant presence of predatory journals in bibliographic databases

The DOAJ case also deserves special attention. On one hand, as Beall's list is a list of academic journals in open access, it is understandable that the figure of 143 predatory journals is higher than those in the databases mentioned in the previous sections. On the other hand, in 2015 DOAJ requested information from the editors about the journals in order to apply more stringent acceptance criteria. As mentioned, this action led to the elimination of 3,300 titles (DOAJ, 2016) that did not answer the survey as well as other reasons (table 8 ).

As a general conclusion we confirm that there is no significant presence of predatory journals in bibliographic databases. As a future investigation, it still remains to evaluate journals from publishers that Beall considers predatory, as well as the analysis of the data found in this study.
Research data of this study can be consulted interactively and is up to date in:

http://miar.ub.edu/recuento/tmp_beall

\section{Note}

1. Calculation from performing periodic analysis by MIAR.

\section{Acknowledgements}

This study was carried out under the project Open access to science in Spain. (CSO2014-52830-P) of the Spanish R\&D Plan funded by the Spanish Ministry of Science and Innovation.

\section{Bibliography}

Anderson, Rick (2015). "Should we retire the term 'predatory publishing'?". The scholarly kitchen, May 11. http://scholarlykitchen.sspnet.org/2015/05/11/should-weretire-the-term-predatory-publishing

Beall, Jeffrey (2012a). "Criteria for determining predatory open-access publishers". Scholarly open access, August 4. https://scholarlyoa.com/2012/08/04/criteria-for-determiningpredatory-open-access-publishers

Beall, Jeffrey (2012b). "Criteria for determining predatory open-access publishers. $2^{\text {nd }}$ edition". Scholarly open access, December 1.

https://scholarlyoa.com/2012/11/30/criteria-for-determiningpredatory-open-access-publishers-2nd-edition

Beall, Jeffrey (2012c). "Predatory publishers are corrupting open access". Nature, v. 489, n. 7415, pp. 179-179. https://doi.org/10.1038/489179a

Beall, Jeffrey (2013). "Predatory publishing is just one of the consequences of gold open access". Learned publishing, v. 26, n. 2, pp. 79-84.

https://doi.org/10.1087/20130203 
Berger, Monica; Cirasella, Jill (2015). "Beyond Beall's list: Better understanding predatory publishers". College \& research libraries news, v. 76, n. 3, pp. 132-135.

http://crln.acrl.org/content/76/3/132.full.pdf+html

Clark, Jocalyn; Smith, Richard (2015). "Firm action needed on predatory journals". BMJ, v. 350, h210.

https://goo.gl/kWCjxE

https://doi.org/10.1136/bmj.h210

Crawford, Walt (2014a). "Ethics and access 1: The sad case of Jeffrey Beall". Cites \& insights, v. 14, n. 4, pp. 1-14.

http://citesandinsights.info/civ14i4.pdf

Crawford, Walt (2014b). "Journals, 'journals' and wannabes: Investigating the list". Cites \& insights, v. 14, n. 7, pp. 1-45.

http://citesandinsights.info/civ14i7on.pdf

DOAJ (Directory of open access journals) (2016). DOAJ to remove approximately 3300 journals, May 11.

https://doajournals.wordpress.com/2016/05/09/doaj-toremove-approximately-3300-journals

Jalalian, Mehrdad; Mahboobi, Hamidreza (2014). "Hijacked journals and predatory publishers: Is there a need to re-think how to assess the quality of academic research?". Walailak journal of science and technology, v. 11, n. 5, pp. 389-394.

http://wjst.wu.ac.th/index.php/wjst/article/view/1004 https://doi.org/10.14456/wjst.2014.16

Matthews, David (2016). "Journals and publishers setting sights on the unwary". Times higher education (THE), January 21.

https://www.timeshighereducation.com/news/infographicjournals-and-publishers-setting-sights-on-the-unwary

Nelson, Nerissa; Huffman, Jennifer (2015). “Predatory journals in library databases: How much should we worry?". The serials librarian, v. 69, n. 2, pp 169-192.
https://goo.gl/H9Bbw3

http://doi.org/10.1080/0361526X.2015.1080782

Oransky, Ivan; Marcus, Adam (2016). “Are 'predatory' publishers' days numbered?" STAT. The watchdogs, September 2. https://www.statnews.com/2016/09/02/predatory-publishers

Rodríguez-Gairín, Josep-Manuel; Somoza-Fernández, Marta; Urbano, Cristóbal (2011). "MIAR: hacia un entorno colaborativo de editores, autores y evaluadores de revistas". EI profesional de la información, v. 20, n. 5, pp. 589-595. https://doi.org/10.3145/epi.2011.sep.15

Shen, Cenyu; Björk, Bo-Christer (2015). "'Predatory' open access: a longitudinal study of article volumes and market characteristics". BMC medicine, v. 13, n. 230. https://doi.org/10.1186/s12916-015-0469-2

Straumsheim, Carl (2016). “Feds target 'predatory' publishers". Inside higher ed, August 29.

https://www.insidehighered.com/news/2016/08/29/federaltrade-commission-begins-crack-down-predatory-publishers

Thomson Reuters (2015). "Emerging sources citation index. Fact sheet". Web of Science.

http://wokinfo.com/products_tools/multidisciplinary/esci

Truth, Frank (2012). "Pay big to publish fast: Academic journal rackets". Journal for critical education policy studies, v. 10, n. 2.

http://www.jceps.com/wp-content/uploads/PDFs/10-2-02.pdf

Vargas, Juan-Felipe (2016). "Hijacked journals: la suplantación de Andamios, Revista de investigación social". Journals \& authors. Soluciones en publicaciones científicas, 7 marzo. http://www.jasolutions.com.co/blog/hijacked-journals-lasuplantacion-de-andamios-revista-de-investigacion-social

Velterop, Jan (2015). “Los 'buenos' barrios cerrados de publicación de Jeffrey Beall". SCiELO en perspectiva, 1 de agosto. http://blog.scielo.org/es/2015/08/01/los-buenos-barrioscerrados-de-publicacion-de-jeffrey-beall

\section{Inforảrea}

Ayudamos a tu organización en la transformación digital y el gobierno de la información

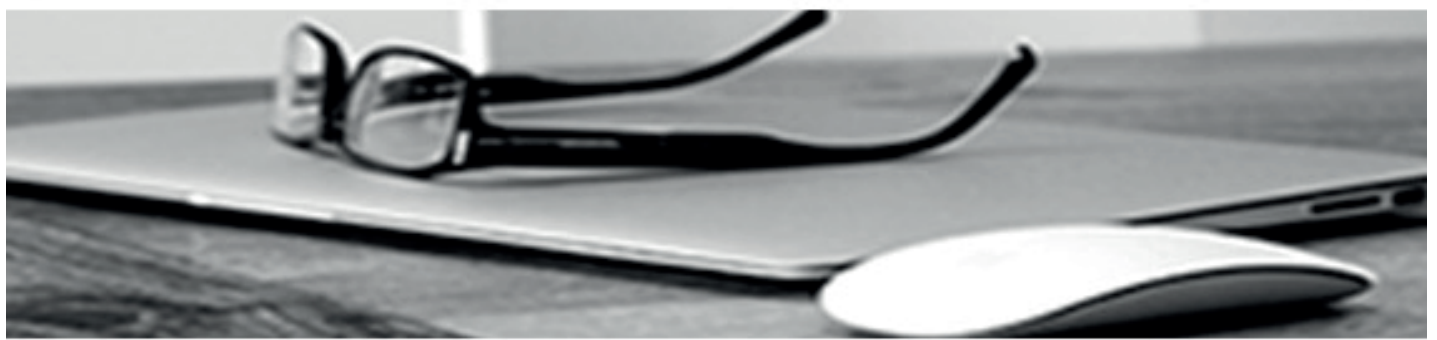

* Consultoría estratégica en gestión y gobierno de la información

* Gestión documental y "records management"

* Gestión de contenidos, intranets corporativas y entornos de colaboración

* Estudios especializados 